\title{
Andalusia Civic Culture at Secondary Schools
}

\author{
Javier Calvo de Mora \\ Universidad de Granada, Spain \\ Soledad Domene Martos \\ Juan Antonio Morales Lozano \\ María Puig Gutiérrez \\ Universidad de Sevilla, Spain
}

\begin{abstract}
:
The construction of a teenager population's citizenship identity is influenced by the cultural and social capital belonging to every student, as well as by two aspects of school organisation. On the one hand, there is an academic contribution motivated by the process of teaching Civic Education and, on the other hand, social connections between school and the milieu. This work studies the development of a teenage population's citizenship identity initiated at schools, and it is based on the outcomes reached by Torney-Purta et al. (2001) and Kennedy et al (2008). The conclusions of the cited works justify the greater knowledge of the identity and awareness of the adolescent Andalusian population. The empirical basis of this approach is based on the works developed by the INJUVE (Spanish Youth Institute). The conclusion of this work is the involvement of an adolescent Andalusian population in traditional practices of citizenship (voting in the elections, abiding democratic laws, etc.) and, on the other hand, the development of civic awareness encouraged by local and family topics. The result of this conclusion is a citizenship educational proposal carried out at schools. It is based on an active learning methodology of the subject of Civic Education and volunteering in a community environment. The aim is to raise active civic awareness among the adolescent population.
\end{abstract}

Keywords: Good citizen, democracy, civic awareness, educational community

\section{Corresponding author: Javier Calvo de Mora}

E-mail: jcalvode@ugr.es

Educational Research eJournal ISSN 2254-0385

(C) Faculty of Education. University of Alicante- Spain

DOI: $10.5838 /$ erej.2012.12.03 


\section{Introduction}

This work creates a connection between two political practices: democracy and citizenship. The concepts of individual and social civic awareness connect both practices. This means every person's ability think and act, the possibility of taking free and responsible choices towards oneself, his/her environment and towards others, and assuming duties towards oneself and the community of belonging: local, national and global. It includes as well the initiative of social groups to create organisations and develop actions for the improvement of a population's life conditions.

Ideas about the interaction between democracy and citizenship show contradictions in the political practice. One example is neo-liberalism, which defines the usage of public and private tools (health and education for example) as opportunities for the individual development of its users. Therefore, the success of every citizen depends on the effort, ability, perseverance, and correct usage of public and private offers available for the population of every country.

The insight of this work about the concept of citizenship is based on participatory democracy, whose ideological frameworks of reference are: status of civic and social rights given by every nation (Marshall, $\mathrm{T}$. 1981, 1977), identity built according to individual circumstances (Barnes, R. 2004), and social identity developed by each social group (Gilbert, 2006). This refers to the citizens' actions of cooperation and collaboration, social inclusion and cohesion, diversity of opportunities, public access to information, and the knowledge of available resources.

The ideology of participatory democracy is broadened by the works of Judith Torney-Purta et al. (2001), Kennedy \&
Chow (2008), and Kennedy, Hahn \& Lee (2006). For example, Tourney-Purta, Leman, Oswald, \& Schulz (2001) emphasise the concept of citizenship identity based in a good civic knowledge; juridical status attribution, which legitimises the usage of public services; obeying the laws of democratic governments; electoral voting; and practical discrimination between democratic and antidemocratic behaviours. In the context of Spanish literature, (Funes, 2008; Martín Cortés, 2006) the connection between citizenship and democracy is based on the same premises mentioned before: the obligation to vote, respect and obedience of the law, action against laws threatening human rights, acknowledgement of political parties as mediators in political representation, and engagement in social movement organisations.

Participatory democracy is the ideal reference point of permanent collective action among a population (Barber, 1984). Its execution depends on the cultural and social capital: social and political development, democratic background, social cohesion and equality, and government structure of every society's political organisations. Thus, the works of García Benítez (2000), Aguiar (1995), and Cazorla (1992) describe the Andalusian society as a society in transition from a rural to an urban culture. It is profiled as a weak entrepreneurial civil society and as having a professionally low qualified cultural capital. On the other hand, corporate governments determine the organisation of Andalusian and Spanish schools in general (Calvo de Mora, 1999, 2006, 2007; Calvo de Mora \& Morales 2008), which control the implementation of rules and regulations of the institutional activity set by the educational administration (Calvo de Mora, 2010).

This social and cultural context here 
described justifies the formation of civic awareness. The basis of this creation is, firstly, the description of the citizen profile, and secondly, the social and educational proposals to improve civic awareness among the Andalusian teenage population.

\section{But, what does citizenship really mean?}

What is citizenship? Is it a concept or a way of living? This work supports the second alternative: it is a way of living influenced by the personal history and the cultural, social, economic and political environments where individuals live or lived, in particular regarding schooling years and educational actions.

The concept of citizenship as a way of living has been studied by reviewing the bibliography of traditional authors (Dewey, 2004/1916; Dewey, 1991/1910; Dewey, 1976/1938; Freire, 2006/1970), who anticipate (in the school environment) the possibility of including social, political and emotional contents in formal and informal curricula. In the formal curricula field, John Dewey supported a form of democratic government at schools and also the teaching of constitutional contents. On the other hand, Paulo Freire organised literacy processes based on personal and emotional topics close to individuals. Due to this fact, he managed to create steady educational programs for literacy on the grounds of meaningful and daily issues from every person's life. Recent publications (Lantieri, 2009; Gómez Llorente, 2005; Barnes, 2004; Lyakhosvetska, Burman, Takeda, Maxwell, Pillas, Wong, 2003; Kurtz, Rosenthal, Zukin, 2003; Bens, 2001) illustrate the emotional and social leadership actions that institutions develop in order to influence cohesion, collaboration, inclusion and innovation processes carried out by members (individually or in groups) and people interested in every institution.

These inputs (school democracy, topics leading to literacy, and emotional leadership) define two basic actions of citizenship: a) Knowledge and understanding of rights, and b) Practice of responsibilities.

\subsection{Knowledge and understanding of rights.}

This domain of citizens' action is included at governmental levels controlling and approving population's constitutional rights in every region. Barnes (2004) qualifies social, political, and personal as well as collective identity rights as a consequence of the acknowledgement of every person's integration in a social, cultural and political group as a citizen. This action of integration denotes knowing and understanding the domain, development, and implementation of civic, social and political rights.

Therefore, governments are promoting school subjects regarding civic knowledge and understanding. In Spain, this practice has recently started. The subject of Citizenship Education and Human Rights proposes a civic learning aimed at students in primary and secondary education in the Spanish educational system. In the last year of upper secondary education, the subjects of Citizenship Education and Human Rights and Ethical and Civic Education aim to develop the following skills:

-To recognise human condition in its individual and social dimension, accepting our own identity and personal features and experiences, respecting differences among each other, and developing self-esteem.

-To develop and express feelings and emotions, as well as social and communicative skills, which allow participation in groups with a supportive and tolerant attitude. To 
solve conflicts through dialogue and mediation.

-To develop personal initiative by assuming responsibilities and developing ways of acting and living together based on respect, cooperation and rejection of violence, stereotypes and prejudices.

-To know, assume and positively value rights and duties derived from the Universal Declaration of Human Rights and the Spanish Constitution. This must be done by identifying its fundamental principles and accepting them as the necessary criteria to ethically evaluate personal and collective behaviours as well as social realities.

-To identify the diversity of current societies by means of recognising it as an enriching element.

-To defend the rights to equality and opportunities among the population by rejecting unfair situations, and discrimination based on sex, origin, beliefs, social differences, affective and sexual orientation or from any other kind, because they go against human dignity and they negatively influence people's coexistence.

-To recognise women's rights, appreciate gender differences and also the equality rights among them. To reject stereotypes and prejudices which may create discrimination between men and women.

-To learn and appreciate the fundamental principles of democratic systems and the administration of the Spanish nation and the European Union, also becoming aware of the common heritage and the social and cultural diversity.

-To learn the basis of a democratic way of living and also to act accordingly in every aspect. To assume the citizens' duties related to the maintenance of common goods and also to recognise the role of the government as the guardian of public services.

-To appreciate the importance of being politically active and also of other ways of citizen engagement such as cooperation, belonging to associations, and volunteering.

-To learn the causes of violation of human rights, poverty and inequality, as well as the relation between armed conflicts and underdevelopment. To give the right value to peace and security actions and to acknowledge active engagement as the solution for achieving a better world.

-To define themselves as members of a global citizenship. To show respect for the habits and ways of living among different populations and to be supportive and helpful with unprivileged people.

-To identify and study the main ethical theories, to identify the main social and moral current conflicts and to develop a critical way of thinking towards the patterns shown through the media.

-To develop a critical thinking, own criteria and skills to support our own points of view in a debate thanks to well-documented and reasonable arguments, also accepting the reasons and arguments from the other parts.

The Universal Declaration of Human Rights, which is the first example of citizenship in the XX century, approved and set into force the 10th December 1987 by the United Nations, and the "Citizenship Indicators" of Bens (2001); Lyakhosvetska, Burman, Takeda, Maxwell, Pillas, and Wong, (2003) are the social and civic precedents of the objectives here described. The political precedents are the Council of Europe's Recommendation 12/2002, which suggests the insertion of the Citizenship Education and Human Rights subject in schools curricula, and the Commission of the European Communities 2005/0221(COD), which sets and defines the eight competences that should be reached in European compulsory education. One of them is the social and civic competence, which 
makes it possible to understand the social reality where people live, cooperate, and practice their democratic citizenship in a plural society at the same time that they engage themselves to improve it.

The social, civic and political frame for understanding people's rights set the basis of the citizenship's definition thorough all educational systems of democratic governments. However, there is a paradox between this global and uniform concept and the diversity of practices that can be seen while teaching the subject as well as through institutional and political decisions towards citizenships at schools.

\subsection{Practice of political and social responsibilities.}

2.2.1 Political responsibilities.

Political and social responsibilities are developed in public, private and nonlucrative institutions as well as in the domain of local communities. Moreover, the question is whether it is possible to assume social and political responsibilities at schools. It means schools' moral and ethical obligation to meet the demands of social and cultural functions. One of these functions is obviously the respect towards a democratic behaviour while broadening and improving organisational processes by taking into account democratic ethic. In a democratic society, every member (students, teachers, families, administrators, etc.) should be involved in what happens at schools, as they belong to the public domain.

In the work carried out by Torney Purta, responsibilities are defined as obligations towards political democracy and democracy at schools. The main citizens' duty in a democratic society is to obey laws. The study developed by Torney Purta (op. cit.) states that an adolescent population identifies itself with the political rights and laws of democracy.
Such identification is established thanks to the civic knowledge of a democratic state and society. One illustrative example is the distinction made between democratic and non-democratic governments in the CiVed'99 Study (IEA Civic Education Study); the interpretation of non-democratic actions fulfilled by governments and institutions; acknowledgment of the characteristics of a democratic society; evaluation of political parties and civic organisations as the main core of regional and national democratic politics, civic knowledge learned at schools, in the family environment, thanks to the media, and mainly through television.

Apart from the respect to democratic laws, a concept of a responsible citizenship has been developed at the level of the European Union. According to the European Union in 2005, the concept of a responsible citizenship embodies issues relating to the knowledge and awareness of civic rights and responsibilities. Moreover, this concept is closely associated with civic values, such as democracy and human rights, equality, participation, participating in associations, social cohesion, solidarity, tolerance to diversity, and social justice. Currently, the European members from the European Council use the concept of a responsible citizenship more frequently, especially after the adoption of important recommendations and resolutions aimed to promote it. In addition, the European Commission has published several White Papers and studies about this topic, which has become a key issue for many European countries.

Political and social actions are considered as the points of reference regarding the concept of a responsible citizenship. On the one hand, in democratic societies' frameworks, the political responsibilities (Birks, 1997; Dagger, 2007; Delue, 1989; Gilbert, 
2006; Klosko, 2005; Parekh, 1993) of every adult and adolescent involve giving the right value to governments actions and demanding the necessary information for that purpose. In other words, the responsibility created by the right to be informed about the governments' performance demands actions such as writing letters of opinion in the newspapers, creating political networks and debates, or participating in political parties and syndicates. Another political responsibility is to fight for the social needs: the creation of new forms of political organisation, the formation of political networks and debates, or other actions intended for the same purpose in order to assume the necessary criteria for political action (Audigier, 2000; Tourney-Purta, Leman, Oswald, \& Schulz, (2001).

The problem of political responsibility is the lack of engagement of the adolescent population according to the parameters of representative democracy (Dalton, 1996; Nie, Junn, \& StehlikBarry, 1996). It is based on the premise that citizens constitute the electorate body obliged to vote in political elections, taking into account the different political options presented by the political parties. On the other hand, the engagement of the adolescent population in family and social environments also has to be taken into account (Hahn, 1998; Shapiro, \& Mahajan, 1986). They focus on public issues that combine knowledge and political action (Owen \& Dennis, 1992) and their social and emotional aspects do not go along with the proposals of professional politics: "Politics as the art of the possible". The result is a poor understanding of political decisions adopted by democratic governments and parliaments.

Another aspect studied by Judith Torney Purta is the responsibility towards education policy. It means the ability to start processes of school government aimed at the development of citizens' individual identity. The underlying idea of the learning process of the subject Civic Education is to promote the autonomy of proceeding and the expression of every school action as the basis of citizenship identity (Arendt, 2008). The main difficulty for school democracy is then the existence of totalitarian practices (non democratic, disrespectful with personal freedom and collective action of every member).

2.2.2. Social responsibilities.

Social responsibilities are also a point of reference in the building and development of civil society, created by volunteering members of non-profitable organisations or from the third sector (Ceslik, \& Pllock, 2002; Eder, 2000). Third sector organisations refer to social structures that contribute to the development of a society defined by entrepreneurship skills, risk-taking actions, problems and solutions, and in favour of the necessary social cohesion for the development of every individual and group. According to our criteria, the characteristics of the civil society leading the actions above mentioned are:

a) Civil society: it is in the debate field where social differences are discussed. Civil society's organisations carry out different actions for the welfare of the state, such as providing social services to groups in disadvantage, or taking into consideration the opinions of people or groups with difficulties to express their demands and worries in social topics.

b) Civil society also means a positive environment for civil rights and freedoms. Political initiative (based on social movements) constitutes the domain of political participation in which occidental democracies are based upon (syndicates, volunteering associations, ecological and feminist organisations). Additional speeches as 
an alternative to professional politics are found in this aspect.

Therefore, citizenship identity is also created in civil society. The key aspects of this creation are known among specific works (Cavia, Gatti, Martínez de Albéniz \& Seguel; 2006; Domínguez, Sádaba, 2005). The first key element is the development of deliberative democracy (Segovia, 2008; Cortina, 2004; Blondiaux $\&$ Sintomer, 2004); the second one, the social innovation towards new political proposals at the local level (Borja, 2000; March, \& Olsen, 1996); the third one is the development of social economies aimed at social solidarity (Chaves Ávila \& Monzón Campos, 2005); and finally the engagement in governmental politics (Cainzos, 2006).

Due to the psychological characteristics of an adolescent population, which is the target group of this work about citizenship identity, we are going to focus in the first place on the social responsibilities of this group regarding political participation. The Spanish Youth Institute (INJUVE) claims that the young Spanish population is centred in personal and familiar issues, as well as in issues regarding the media and relationships. For this reason, social responsibilities assumed by this population remain local and emotional. The cause of these areas of interest is, on the one hand, a feeling of security and certitude among population and, on the other hand, the need of emotional and personal security that encourages to highly value family and friends. The information received from the media is also taken into account.

These areas of social worries can be linked to the age and institutional environments where adolescents coexist: school, group of friends created in these environments, and also their families. Another critical issue is, in general, the media: television, Internet, cell phones, and social networks.

\section{Characteristics of citizenship identity of adolescent population.}

Studies about the adolescent population in Spain (Funes, 2008; Megías Valenzuela, 2005) show the following identity features: optimistic view of social, cultural and economic reality; they consider themselves emotionally fulfilled; and they give high importance to family, health, group of peers, work and earning money. However, regarding the purpose of this work, studies show that they are not very interested in politics and highly interested in social issues: getting a job, fighting against domestic violence, supporting global peace, demanding the distribution of wealth, the right to a decent life for everybody, and environmental protection.

These interests depend on their ideology in the areas of personal issues, family, media and friends. The adolescent populations that declare themselves centrists emphasise personal interests, family, following the media, and friends. Those considered from left wing also give emphasis to the same interests. Right wing and extremist right wing adolescent population are a minority. They highlight the media and their families as the elements that make them react.

All these interests are linked to aspects that foster confidence. Chart I shows the references to social confidence, which complete the group of social interests of the adolescent population. The definition of confidence is understood by the "channels of expression and participation" used. According to Chart I, the Internet, schools and cell phones are the three main channels of expression and participation. It is related to the importance given to personal issues, groups of peers and family. Emotional and social proximity creates confidence. The question is to know which aspects of school institutions and the Internet foster confidence among the adolescent 
population. The most plausible hypothesis is the group of friends made at schools and, on the other hand, the social networks where they belong.

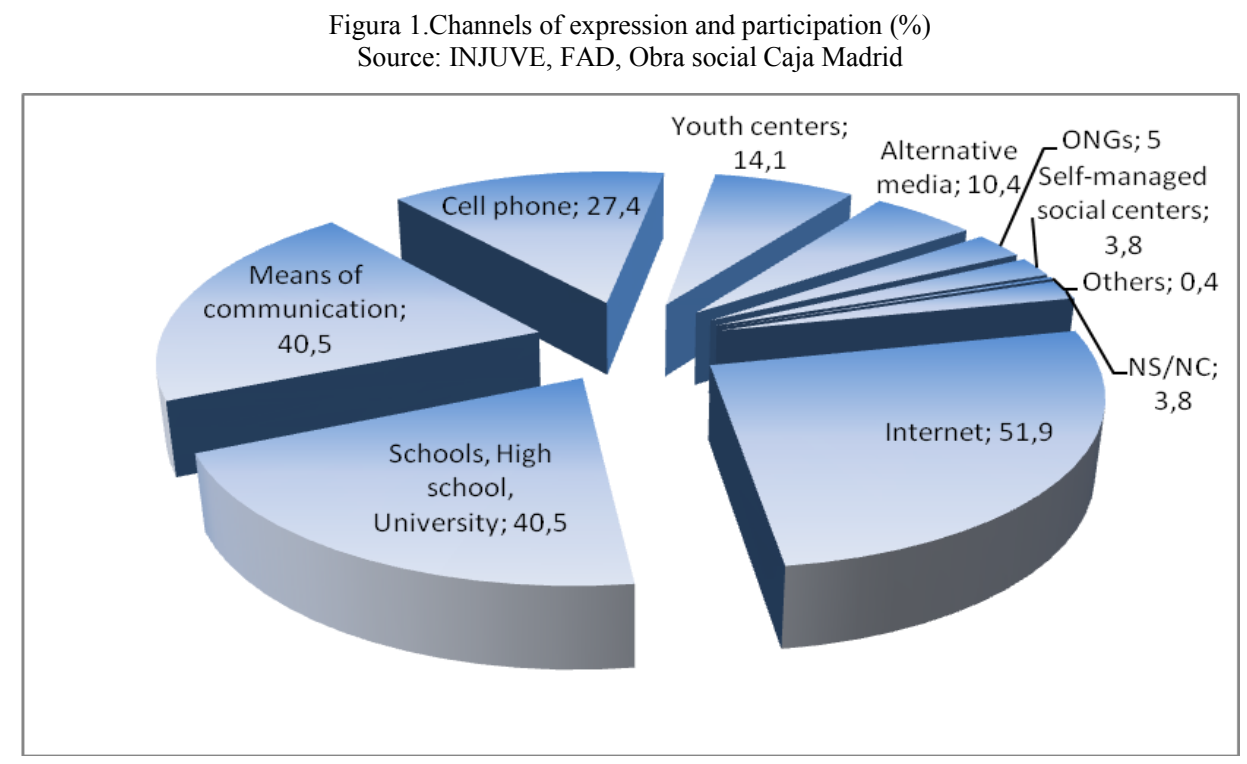

Which are the consequences of this social confidence profile among the adolescent population? Actually, it defines two aspects of social identity among this population: firstly, the division between politics and engagement and, on the other hand, their perceptions about institutional politics. Regarding this last aspect, some authors have described adolescents with the term passive citizenship (Bempechat, 1990; Grolnick, \& Slowiaczeck, 1987; Stevenson \& Baker, 1987). Concerning the first aspect mentioned, another group of authors has created the term reluctance to political participation (Benedicto \& Morán, 2002; Rodríguez, Megías \& Sánchez, 2002; Alonso, 1999). The subject of Citizenship Education and Human Rights (BOE, Number 293, 2006; BOE, Number 5, 2007) thought for primary and secondary education in Spain has been created in order to change this negative tendency regarding social and political participation.
2.1. Social and cultural influences in the creation of citizenship identity

The studies of Torney Purta (op. cit.) and Kennedy (2010) aim at creating a connection between three concepts: cultural capital, social capital, and the perception of a "good adult citizen" among an adolescent population. The results obtained above reflect the impact of the social capital in the practice of active citizenship and the influence of cultural capital in the political participation of adolescent population (Torney-Purta, Schewille \& Amadeo, 1999; Cote \& Healy, 2001; Edwards et al., 2003; Benedicto \& Morán, 2002; Funes, 2008). In conclusion, adolescents who understand institutional politics as a way of participation are those whose families, social and emotional environments give personal value to politics identifying it with representative democracy. This was already mentioned in other works (Coleman, 1997; Coleman, 1998; Bourdieu, 1980) regarding social status and school performance of secondary education students.

The idea of a "good adult citizen", to 
which adolescent population attribute correct values and rules of behaviour, is the result of the social and cultural capital of every student. The references for the definition of this concept are (TorneyPurta, 2001): respecting the laws, voting, participating in politics, trusting institutions, patriotism and women's rights.

a) Obeying democratic laws and voting in the elections.

The study of Torney Purta (2001) states the identification of adolescent population with the laws and political rights of democracy. These patriotic obligations (Müller, 2006) constitute the axis of democracy and democratic citizenship. Regarding liberal democracy, electoral voting legitimises political power. It means the adoption of rules and values among adolescent population as actions of inclusion and cohesion regarding population in general: a citizen, a vote. On the other hand, democratic citizenship is based on values and rules shared by society (regional, national and international) such as political stability, and implicit collective responsibility to respect democratic laws.

b) Political participation.

Regarding the responsibility created by the existence of laws and democratic societies, an adolescent population is moderately interested in active traditional politics: affiliation to political parties, volunteering in non-profit organisations, writing protest letters, or other typical actions of the practice of democratic laws. The nuance of this engagement in active politics is the obligation to vote in democratic elections. They are mainly influenced by political information spread by the media based on surveys and electoral campaigns. This creates a paradox in an adolescent population's civic identity: they are not politically mobilised, but they understand voting as a citizenship obligation. This is due to the knowledge and responsibility to vote in political elections, although adolescents are more interested culturally and emotionally in actions regarding their own lives and daily interests. Therefore, adolescents living in familiar and social environments interested in political issues combine knowledge and political activity. However, the difference between adolescent boys and girls regarding knowledge and political activity is maybe due to the discriminatory processes of political socialisation coming from the media (especially television), which attribute a male image and male values to institutional politics.

c) Trusting governmental institutions.

A key element of a citizenship's identity is to trust democratic institutions (Luhmann, 1979, 1988) and to understand them as a voluntary agreement between professionals and users. The foundation of this agreement is to reduce the complexity and uncertainty of institutions' running and, on the other hand, to foresee the consequences of the decisions adopted by professional members. These two actions influence the participation of the population in institutions: the value of trust, and their involvement in public and private institutions (Misztal, 1996). It helps to prevent and assume risks that normally dissuade people.

The difference regarding contents and reality between political institutions and social and cultural politics appears in the work of Torney Purta et al. (TorneyPurta, Schwille \& Amadeo, 1999): an adolescent population moderately trusts governmental institutions (except police and the judiciary system).

This environment of mistrust towards the government and its institutions is globally due to a passive perception of a citizenship's identity (World Values Survey, McAllister 1999) more based on the fulfilment of personal objectives than on the effort to achieve individual and collective goals. In other words, 
adolescents trust more in organisations and institutions devoted to one issue in particular (immigration, women's rights, care of homeless people) than in governmental institutions whose generic actions (social services, education, health, parliament, etc.) are not clearly defined due to the rendering of universal services set on the grounds of standards and quality with no reference to the assistance of individual needs. Furthermore, the perception of no internal democracy in public institutions (devoted to collective interest) goes against individual benefits of every citizen. Denmark, Norway and Sweden are the countries whose adolescent population trusts more in the governments' institutions in comparison with the lower percentages of Bulgaria, the Russian Federation and Slovenia. The immediate consequence of trusting the government and its institutions is the participation of the population.

d) Patriotism and immigration.

The definition of patriotism is the acceptance by every citizen of the values, symbols and culture of every region, nation or state, but it is a contradiction in itself. The reasons for the contradiction between patriotism and citizenship are: the obligation of having a single perception about "nation" that excludes critical views of people who recognise injustices done in the name of "the common good" of the nation or "for the benefice of the state". Moreover, political societies are not created on the grounds of a stable consensus and unique respect to issues such as peace, international order, citizens' rights, and obligations to national loyalty.

However, despite these contradictions, patriotism is a collective identifying element towards some symbols and basic actions. Therefore, this study about patriotism focuses on basic contents: knowledge of the country's history and recruitment for the army in order to defend the country. The knowledge of the history of every country is carried out mainly in secondary education in order to encourage the identification of an adolescent population with their "homeland". Such identification means being proud of the country where they live (either because they were born there or because they permanently moved there). Which is the contribution of patriotism to the citizenship identity of an adolescent population? There is not a clear answer, although high percentages of positive perception towards the nation of origin are shown, no matter the gender of the adolescents. According to our work, this is an interpretation of the existence of cultural identity and thus, representative and social basis that foster the cohesion among the population of every nation. This is also stated in the relevant works of nations and national cultures (House, Hanges, Javidan, Dorfman, \& Gupta, 2004) spread by the media, the history and available channels for states in order to create united societies included in patriotic symbols.

This inclusive patriotism is the term created by Torney Purta in order to define the acceptance of immigrant populations in the context of democracy when they assimilate the basic norms of conviviality and symbols such as the flag and the constitution, among others. Nevertheless, this positive attitude towards immigration depends on the educational qualification of every adolescent's family. At the same time, the interaction with immigrant populations at school is another circumstance that influences the positive attitude (more girls than boys) towards immigration, but only in the limited context of national rules and the recognition of symbols.

e) Women's rights. 
On the other hand, social cohesion and respect to diversity is important in most of the affirmative answers about defending political, social, economic, religious and birth control rights, especially in countries of central and northern Europe with strong democratic tradition and mentality regarding relations and structures of civil society.

In general, adolescent populations support women's economic and political rights: around $60 \%$ of the population, which shows a civic awareness of adolescents regarding their rights. Female adolescents declare that they have the same rights to an equal salary and job, participation in political life, the same qualification for political leadership and access to qualified jobs during economic crisis and shortage of job opportunities.

\section{Learning how to be a citizen.}

It is difficult to understand the learning and acquisition process of citizenship identity by the adolescent population when the departing point is a simple causal relation: teaching Civic Education and making a balance of the characteristics of a good adult citizen. It is rather the social and cultural capital (physical or through the media) that influence in the collective perception of a "good adult citizen", together with the ability to think and act of every adolescent.

Therefore, learning how to be "a good citizen" is an ambitious process throughout one's entire life. Adolescents learn civic actions at schools, as well as in their social and cultural environments, and the question is: Who has more influence in this learning process? The conclusions of the CiVed Study are the influence of the socioeconomic and familiar environments in the learning process of citizenship skills and abilities (Lutkus, Weiss, Campbell, Mazzeo \&
Lazer, 1999; Torney- Purta, 2000), and also the teaching methodology of Civic Education. Regarding the aspects related to the practical knowledge of citizenship, the grade of intensity of the learning process determines the importance given to the skills and abilities learned.

\section{Civic awareness of adolescent population in Andalusia.}

Citizenship knowledge or the adoption of an individual and collective way of living regarding active citizenship requires a deep civic awareness (Iyamu y Obiunu, 2005; Cheung, Chan, Liu, Leung, 2004). In other words, thinking and acting according to practical issues affecting individuals for moral, ethical, political or ideological reasons. On the other hand, the superficial (or conventional) learning process of civic awareness among citizens is based on the acquisition of curricular material without practical implementation beyond the recognition, discrimination and evaluation of citizenship's practices.

The acquisition of superficial or deep civic awareness (that means learning about citizenship in class or in social and cultural environments respectively) is well documented by current works about Civic Education (Janowitz, 1983): citizenship teaching methods, selected issues for fostering civic awareness, and typical elements of civic awareness among adolescent population.

Civic awareness among Andalusian adolescents, as in other European populations, deals with the citizens' behaviour influenced by the social and cultural context. On the one hand, the influence of the subject Citizenship Education and Human Rights; and, also, influences coming from families and also from cultural trends dominating the civil society of belonging. This learning context encourages the hypothesis of a 
superficial acquisition of civic awareness by Andalusian adolescents.

\subsection{A learning method for civic awareness.}

Educational legislation in Spain regarding Civic Education (BOE, 2006, BOE, 2007) does not differ from the directives of the European Commission (Eurydice 2005) regarding the contribution of this subject to the learning process of social and citizenship competences in primary and secondary schools: competence for learning how to learn, competence for personal autonomy, and competence for linguistic communication. At the same time, Spanish legislation highlights the importance of a methodology based on dialogue. Therefore, according to the social and citizenship skills learned through dialogue, Spanish legislation conclude five types of results to be achieved thanks to this subject during compulsory education levels:

-Civic knowledge: human rights, knowledge of the key points of institutional politics, political history, human and ideological diversity, cultural heritage of every country, basic legislation of representative democracy, and the population's influence in politics.

-Civic competences and abilities: creativity, research ability, critical thinking, communication, skills for debating, active listening, problem solving, working in groups, conflicts solving, and well thought decision-taking. -Civic attitudes: trust in politics, interest in political issues, autonomy and independency, resistance ability, value for the national culture, respect for other cultures, open-mindedness for change, and responsibility.

-Civic values: human rights, democracy, ethnic and gender equality, sustainability, and peace.

-Citizenship identity: sense of personal identity, sense of community identity, sense of national identity, and sense of global identity.

The extent of these results requires a learning process depending mainly on the epistemology of the subject and also on the teaching process in the classroom, as well as the implementation of the contents in real life. In the case of Civic Education regarding Philosophy, the methods for learning values implemented in the classroom have been considered as a decision between an absolute and unchangeable concept of values, and the relativist concept of citizenship values:

According to the Educational Technologies Institute (ITE) from the Spanish Ministry of Education (MEC) in 1992, it is a set of actions intended for the students to create their own values and rules, as well as to adopt coherent attitudes and to act consequently.

For example, if the subject of Civic Education is regarded in the context of the epistemologies of critical awareness (Delors, 1996; Kennedy, Lee \& Grossman, 2010), the research methods for the action and socio-cultural animation (Reason \& Bradbury, 2002) are appropriate in order to acquire citizenship knowledge. This is due to the critical thinking of every student and teacher as active citizens (Benedicto \& Morán, 2002) in primary and secondary schools, and also in the communities of public spaces of belonging, in order to: -Create active citizens' networks in the field of social networks to which students belong.

-Provide opportunities to encounter active citizenship experiences, strengthening the experience among equals and families.

-Develop informal conversations.

-Create political speeches based on issues relevant to the community.

-Generate democratic environment at schools.

This environment of experience learning 
about citizenship demands new organisational social areas between schools and communities: interaction among different organisations with common purposes. Moreover, the interaction between academic, political, social and emotional contents influences the learning process and the global understanding of the social and cultural reality of every citizen. The challenge here is to maintain a stable development of this inclusive and global process of citizenship knowledge.

According to our point of view, active citizenship in primary and secondary compulsory education means taking part in volunteering actions. Volunteering is one of the key elements for the democratic change among a society (Hollander, Saltmarch, Zlotkowski, 2001). It is also fundamental for the development of the citizenship concept and the re-establishment of the sense of community. Volunteering (Community Service Volunteers) contributes to solidarity, fosters participation and protects groups against social and economic discrimination. The intensity and frequency of citizens' engagement through volunteering actions is considered as an element of belonging to social participation and also an improvement to the social capital of every community and organisation (Chaux, 2005; O'Brien, 2008; Reimers, 2006; Giddens, 2003; Dede, 1992). Civic awareness of the population here is the main aspect of the creation of a civil society based on participatory democracy and responsible citizenship (Pares, 2009).

The learning process of citizenship beyond the classroom combines teaching, learning and thinking: through this method, the students apply the knowledge acquired about citizenship in issues of real life in their own communities.
5.2. Topics fostering civic awareness.

Topics fostering civic awareness (Freire, 1972, 1973; Vygotski, 1997) are originated through social relations and are developed according to the story of every person and social group, political cultures, and social institutions where individuals live. For this reason, Andalusian adolescents are culturally and socially related to social and familiar issues, as well as to the most worrying and debated issues through the media: housing, unemployment, and also peace, environmental sustainability, as well as the conditions of public services in education (Funes Rivas, 2008; CIS, 2009).

The question raised by both social and political issues is the priority and influence in the development of civic awareness. This means how adolescents react to issues such as the raise of unemployment, housing difficulties, or the deterioration of the environment: through participation in social organisations, supporting demonstrations against unfair situations, and writing letters to newspapers among other actions.

To be aware of these social problems is unavoidable (due to the media). Problems such as unemployment or housing shortage foster the creation of civic awareness when they are faced in the familiar and local environments (Taglioli, 2007; Tezanos, 2007). However, other less direct issues (such as defending human rights, defending the homeland, or assuming religious views shared by other individuals) are issues of a citizens' knowledge, but maybe not of civic awareness. This distinction, which depends on emotional and experiential proximity, influences the creation of a stronger or weaker civic awareness. In the second concept, problems and worries are identified as existing issues, but do not foster social or political actions. A different 
knowledge process defines strong civic awareness: presentation of the problem, discussion of the issues, individual and collective action in order to solve unfair situations, and the evaluation of the improvements done.

\subsection{Elements of civic awareness of Andalusian adolescent population.}

The aim of the study about civic awareness is to identify the predominant type among Andalusian adolescents. A weak civic awareness is characterised by the understanding of the obligation of political and social participation as a constitutional requisite for the creation and support of democratic governments. Moreover, it is civic awareness towards the respect of the defence of every nation's values.

A strong civic awareness is defined by the changing of the social, political, economic and cultural reality of the community, religion or country of origin. This action of change is developed thanks to the obligation to participate in critical associations towards governmental politics, volunteering, concerns about community problems, and disobedience to laws considered unfair (Naval, 2008) among others.

The three points of reference regarding weak and strong civic awareness are the following:

-Political obligation. How does an adolescent perceive political obligations of an adult population? Obligations about representative democracy and democratic institutions related to the influence of citizenship in its administration are shown here. The rights (well-manifested or protected) obtained by citizens as contributors to the state must also be mentioned. These political obligations refer to the knowledge and conventional behaviour of the citizens belonging to a democratic country: voting in the elections for the different political levels, and affiliation to political parties or debates about political issues more or less relevant for the population.

-Civic obligation. It is the obligation regarding social movements linked to a stronger civic awareness. The goal is to study the perception of the adolescent population regarding social cohesion and diversity. An important indicator of civic obligations is to check the strength of civil society. This means participating in activities for supporting citizens' rights, criticising unfair laws, actions towards protecting the environment, and some others. It is important to investigate whether or not adolescents belong to non-profit organisations, where it is possible to fight for social rights, women's rights, engage in the community, and immigrants' rights.

-Patriotic obligation. This dimension of civic awareness raises aspects of obligations regarding national identity, based on a common ideal shown in legal and social rights of belonging to the country and obligations of national defence, deeply rooted in some countries.

\section{Outcomes of the CiVed'99 Questionnaire in Andalusia.}

The study of civic awareness is an approach based on the opinions of adolescents from Andalusia thanks to the CiVed'99 questionnaire (TorneyPurta, 2001). This questionnaire was answered in spring 2009 by 1133 fourteen year-old students living in the provinces of Seville and Granada (Andalusia). This means $17 \%$ of the schooling population in both provinces. With this study, it is intended to verify the connection between this population and others already studied in the European context.

In a first approach, the answers of the 
questionnaire shown in Table 1 will be described using frequencies and percentages. This data illustrates the appreciation of this group of adolescent students regarding the concept of a "good adult citizenship". It is a subjective perception that shows what they think about being or not being an adult citizen. Students were asked the following: "For each of these sentences, check the box corresponding to what you consider important in order to explain what it means, or what it should mean to be a good adult citizenship". The different answers represent four points in the Likert scale: very important, moderately important, of little importance, unimportant (Schulz \& Sibberns, 2004).

\begin{tabular}{|c|c|c|c|c|c|c|c|c|}
\hline \multicolumn{3}{|c|}{$\begin{array}{c}\text { ANDALUSIA } \\
\text { An adult person is a good citizen if he or she... }\end{array}$} & \multirow{2}{*}{\begin{tabular}{|c|} 
Unimportant \\
14
\end{tabular}} & \multirow{2}{*}{$\begin{array}{c}\begin{array}{c}\text { Of little } \\
\text { importance }\end{array} \\
36\end{array}$} & \multirow{2}{*}{$\begin{array}{c}\text { Important } \\
389\end{array}$} & \multirow{2}{*}{$\begin{array}{c}\begin{array}{c}\text { Very } \\
\text { important }\end{array} \\
680\end{array}$} & \multirow{2}{*}{\begin{tabular}{|c|}
$\begin{array}{c}\text { I do not } \\
\text { know/it is not } \\
\text { relevant }\end{array}$ \\
14
\end{tabular}} & \multirow{2}{*}{$\begin{array}{c}\Sigma \\
1133\end{array}$} \\
\hline$D_{1}$ & Is loubidino & $\mathrm{f}$ & & & & & & \\
\hline D1 & IS Idw dolung & $\%$ & $1,24 \%$ & $3,18 \%$ & $34,33 \%$ & $60,02 \%$ & $1,24 \%$ & $100 \%$ \\
\hline \multirow{2}{*}{ B2 } & \multirow{2}{*}{ Votes in every election } & ff & 184 & 330 & 422 & 155 & 42 & 1133 \\
\hline & & $\%$ & $16,24 \%$ & $29,13 \%$ & $37,25 \%$ & $13,68 \%$ & $3,71 \%$ & $100 \%$ \\
\hline \multirow{2}{*}{ B3 } & \multirow{2}{*}{ Is affiliated to a political party } & $\mathrm{f}$ & 529 & 376 & 125 & 37 & 66 & 1133 \\
\hline & & $\%$ & $46,69 \%$ & $33,19 \%$ & $11,03 \%$ & $3,27 \%$ & $5,83 \%$ & $100 \%$ \\
\hline \multirow{2}{*}{ B4 } & \multirow{2}{*}{ Works hard } & "f & 73 & 162 & $\overline{2549}$ & 317 & 32 & 1133 \\
\hline & & $\%$ & $6,44 \%$ & $14,30 \%$ & $48,46 \%$ & $27,98 \%$ & $2,82 \%$ & $100 \%$ \\
\hline \multirow{2}{*}{ B5 } & \multirow{2}{*}{$\begin{array}{l}\text { Would participate in a pacific } \\
\text { protest against an unfair law }\end{array}$} & $\mathrm{f}$ & 153 & 369 & 313 & 206 & 92 & 1133 \\
\hline & & $\%$ & $13,50 \%$ & $32.57 \%$ & $27.63 \%$ & $18,18 \%$ & $8,12 \%$ & $100 \%$ \\
\hline \multirow{2}{*}{ B6 } & \multirow{2}{*}{$\begin{array}{l}\text { Knows the history of his/her } \\
\text { country }\end{array}$} & $\mathrm{f}$ & 167 & 358 & 394 & 162 & 52 & 1133 \\
\hline & & $\%$ & $14,74 \%$ & $31,60 \%$ & $34,77 \%$ & $14,30 \%$ & $4,59 \%$ & $100 \%$ \\
\hline \multirow{2}{*}{ B7 } & \multirow{2}{*}{$\begin{array}{l}\text { Is willing to join the army to defend } \\
\text { his/her country }\end{array}$} & ff & 389 & 331 & 243 & 94 & 76 & 1133 \\
\hline & & $\%$ & $34,33 \%$ & $29,21 \%$ & $21,45 \%$ & $8,30 \%$ & $6,71 \%$ & $100 \%$ \\
\hline \multirow{2}{*}{ B8 } & \multirow{2}{*}{$\begin{array}{l}\text { Is informed of daily politics } \\
\text { through newspapers, radio or } \\
\text { television }\end{array}$} & 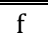 & 213 & 366 & 383 & 125 & 46 & 1133 \\
\hline & & $\%$ & $18,80 \%$ & $32,30 \%$ & $33,80 \%$ & $11,03 \%$ & $4,06 \%$ & $100 \%$ \\
\hline \multirow{2}{*}{ B9 } & \multirow{2}{*}{$\begin{array}{l}\text { Participates in activities that } \\
\text { benefit the people from his/her } \\
\text { community (society) }\end{array}$} & f & 89 & 300 & 497 & 204 & 43 & 1133 \\
\hline & & $\%$ & $7,86 \%$ & $26,48 \%$ & $43,87 \%$ & $18,01 \%$ & $3,80 \%$ & $100 \%$ \\
\hline \multirow{2}{*}{ B10 } & \multirow{2}{*}{$\begin{array}{l}\text { Respects the representatives of the } \\
\text { government (leaders, civil } \\
\text { servants) }\end{array}$} & $\bar{~} \bar{f}$ & 104 & 245 & 515 & 215 & 54 & 1133 \\
\hline & & $\%$ & $9,18 \%$ & $21,62 \%$ & $45,45 \%$ & $18,98 \%$ & $4,77 \%$ & $100 \%$ \\
\hline \multirow{2}{*}{ B11 } & \multirow{2}{*}{$\begin{array}{l}\text { Participates in activities in favour } \\
\text { of human rights }\end{array}$} & $\mathrm{f}$ & 77 & 225 & 506 & 274 & 51 & 1133 \\
\hline & & $\%$ & $6,80 \%$ & $19,86 \%$ & $44,66 \%$ & $24,18 \%$ & $4,50 \%$ & $100 \%$ \\
\hline \multirow{2}{*}{ B12 } & \multirow{2}{*}{ Is involved in political debates } & f & 378 & 479 & 153 & 40 & 83 & 1133 \\
\hline & & $\%$ & $33,36 \%$ & $42,28 \%$ & $13,50 \%$ & $3,53 \%$ & $7,33 \%$ & $100 \%$ \\
\hline B13 & Participates in activities to protect & f & 94 & 219 & 462 & 325 & 33 & 1133 \\
\hline D10 & the environment & $\%$ & $8,30 \%$ & $19,33 \%$ & $40,78 \%$ & $28,68 \%$ & $2,91 \%$ & $100 \%$ \\
\hline B14 & Is patriotic and loyal to his/her & f & 187 & 310 & 384 & 185 & 67 & 1133 \\
\hline D14 & country & $\%$ & $16,50 \%$ & $27,36 \%$ & $33,89 \%$ & $16,33 \%$ & $5,91 \%$ & $100 \%$ \\
\hline B15 & Is willing to ignore a law that go & (f & 207 & 172 & 292 & 298 & 164 & 1133 \\
\hline D10 & against human rights & $\%$ & $18,27 \%$ & $15,18 \%$ & $25,77 \%$ & $26,30 \%$ & $14,47 \%$ & $100 \%$ \\
\hline
\end{tabular}

Table 1: Opinions about citizenship of Andalusian adolescents. 
The interpretation of the answers obtained can be divided into three types: a) opinions regarding conventional politics; b) opinions regarding social movements; c) opinions regarding the correct adult behaviour towards social issues. The conclusion of these interpretations is the type of civic awareness that identifies Andalusian adolescents.

Firstly, the fact that "Being law abiding" is the aspect where they reached the highest consensus is remarkable, and it differs from the answers of "Ignore a law that goes against human rights", "Be patriotic and loyal to his/her country" and "Be willing to join the army to defend his/her country". The preliminary conclusion is that they globally accept conventional citizenship behaviours, but that they do not give that much importance to involving themselves in social movements related to citizenship, and that they also reject the concept of the military defence of the nation. The question raised here is to find out which elements influence these answers.

On the one hand, it seems that abiding the law is an issue often spread by the media, taught in the family context and at schools. It is also fostered by Andalusian culture, defined by the concept of "integrity". It means abiding the laws, complying with the established rules, avoiding uncertainty by following the norms and acting according to the established law. On the other hand, breaking an unfair law reinforces the concept above-mentioned: individuals must obey the laws, but protests against unfair laws are collective actions of civic awareness. However, it is not known if the rejection to collective actions is influenced by the fact that they do not know about the existence of civic organisations fighting for civil and working rights (syndicates, ecological or women's right organisations), or if they are against the fact of participating in collective actions involving certain risk.
The hypothesis here developed is oriented to the second option for two reasons: firstly, adolescents study in the subject Citizenship Education and Human Rights the history of social movements, for example the history of workers' syndicates fighting against unfair laws.

Moreover, the answer to the question "Work hard" is considered as important or very important in the $70 \%$ of the answers, and it shows an individualistic view of civic awareness. Therefore, students in secondary schools know the history of social movements (almost 50\% of them state that adults must know the history of their nation). However, the culture based on individual interests has more influence than the subject of Spanish Civic Education, which intends to create collective action.

Another particular aspect of adolescent population in Andalusia is the high respect to political authorities and politicians. More than $50 \%$ state that a good adult citizen "Respects the representatives of the government". However, as in other European regions, they are not in favour of affiliation to political parties: more than $70 \%$ declare that it is of little importance or unimportant to be affiliated to a political party. This reinforces the idea of an individual view of civic awareness among this population: participating in a political party, syndicate, or in a civic organisation means a solidarity effort, volunteering and altruism to act without direct benefits for every participant. Thus, as compared in the literature studied for the realisation of this work, an adolescent population has an approach to citizens' action that has an impact on individual benefits and welfare. What illustrates this individual view of citizenship is the poor interest in political knowledge (meaning the government of the common good) shown in the answers of "Is informed of daily politics through newspapers, radio or television" and "Is involved in 
political debates". The results obtained confirm that more than half of the interviewed population does not consider being familiar with news about politics as a value of the good adult citizen. The area of interest of the adolescent population is not centred in institutional politics, but in the family, friendship, social networks, and personal issues. Institutional politics is something distant and not often understood by this population.

The third aspect studied is the perception of adult behaviour regarding local issues. On the one hand, more than $60 \%$ consider it important or very important to "Participate in activities that benefit the people from his/her community", "Participate in activities in favour of human rights", and "Participate in activities to protect the environment". These answers constitute an alternative view to the individual awareness explained before. There is a collective civic awareness about social and emotional issues close to the adolescent population in different areas: neighbours, people whose rights are violated, such as immigrants, poor people, deprived people due to drug addiction, and others. Furthermore, they regard the defence of the environment (apart from the global interpretation) as particular actions close to them: recycling, cleaning the streets, preserving the environment, planting trees among other actions carried out in secondary education schools. This aspect has been mentioned before: civic awareness is created through issues related to the personal experience of adolescents. Thus, in this work, it can be confirmed that social and emotional proximity to problematic issues fosters civic awareness.

Interpretations of Table 1 raise the following question: Why do the adolescents identify the good adult citizen as a person involve in local issues and not in issues of institutional politics such as political debates, political information or participation in political parties? Another question raised is the acceptance of democratic laws and professional politicians in the context of representative democracy and the low importance given to the idea of a good adult citizen involved in social movements.

The illustration of the two questions is shown in Table 2, where the factors and factorial loads obtained in the analysis carried out thanks to the statistics program SPSS (KMO and Bartlett's test) are presented. The relationships between the studied items and their influence in civic awareness (individual and collective) of adolescent population can be observed here.

\subsection{Views about political obligations.}

The list of political obligations (voting in the elections, abiding the law, participating in a political party, following the news in the newspapers, being involved in political debates, and protesting against unfair laws) constitutes their opinions towards what means being an adult. Adolescents see these items as political obligations. However, they do not consider them as important as other aspects: political obligations only moderately influence (with a factorial load of 0.58 ) in the creation of civic awareness; in other words, the elements that foster action and justify citizenship action.

This outcome is the consequence of the civic knowledge acquired in the subject Citizenship Education and Human Rights in the third year of Spanish secondary education. The contents learned about conventional citizenship are the participation in the elections, the political parties as mediators of political representation, and the interpretation of the news in the media, among other similar contents of representative democracy. They are recognised more as 


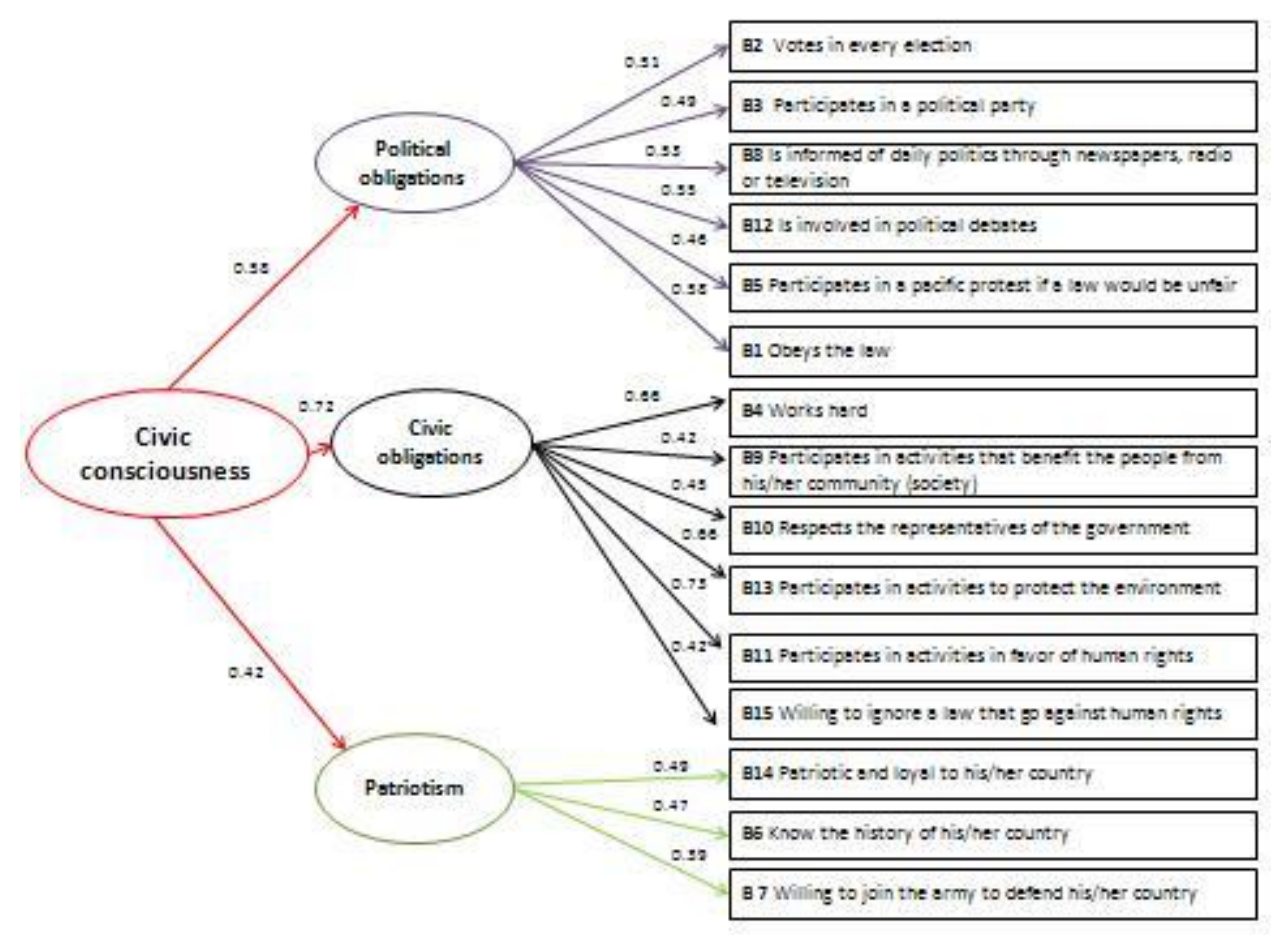

Table 2

political obligations, and defined less as reasons for fostering a citizenship's action towards creating civic awareness. On the other hand, the implied definition of democracy is given through the perception of political obligations. Democracy as a political regime and not as a process of social daily relations is an example. The main relation in Table 1 is voting in the elections as a process of awareness of political obligations. Nevertheless, being involved in political debates (as a democratic process) conforms a percentage of $30 \%$ among the adolescent population. This preference of the regime above the democratic process is the result, among other works (Ichilov, 1990; McNeal, 1999; Husfeldt, Barber \& Turney-Purta 2005), of the weak confidence in school participation and the participation in political activities. Regarding school participation (TheissMorse, \& Hibbing, 2005), and in general public institutions, it is intended to create an interest in individual purposes, in the personal welfare, and less in the improvement of the social capital of institutions and organisations. In other words, the confirmation of political subjectivity at schools and other institutions influence the practice of democratic approaches in education: someone is democratic if he/she can devise an individual benefit.

\subsection{Views about social obligations.}

The power of the interest in individual benefits (Beck, \& Beck-Gernsheim, 2002) confirms the influence of neoliberal democracy regarding a social perception of democracy. Therefore, social obligations seen as important by the adolescent population have more power in the civic awareness of citizens. The goal of the hypothesis about subjective civic awareness is to examine the predisposition of adolescents to become involved in some activities of social citizenship, as well as their insights about the democratic regime.

More than two thirds of the population are in favour of participating in issues that foster social awareness in a local context: actions for the defence of human rights' laws and actions to 
support peace and environmental sustainability. Thanks to this insight, it can be deduced that the adolescent population does not make the connection between the democratic regime and the engagement in the community where it belongs. In the traditional political theory, democracy and community participation (Blossfeld, Kljzing, Mills, \& Kurz, 2005; Iacovou, \& Berthoud, 2004) support the integration of both models of democracy (participatory and representative) with the methods of action corresponding to each one of them. For example, representative democracy is based on the method of election (thinking process and choice) and participatory democracy on the method of deliberation (thinking process and choice) learned thanks to volunteering, the creation and participation in social networks, and other similar actions.

Another conclusion is, apart from the influence of social obligations in civic awareness, the lack of a working method at a community level, which should be the methodology to teach the subject Citizenship Education and Human Rights. Otherwise, the learning results of this subject (knowledge, skills and competences, attitudes, values and citizenship identity) come from explanations and not from experiences in the social and cultural environment of adolescents. This is proved by the importance given to the statement "Participate in activities benefiting the community" in the category of social obligations.

The process of political socialisation among adolescent population (shown in the perceptions of the good adult citizen) is influenced by the division of political, socio-economic and emotional categories (European Council, 2001; European Council, 2003). On the one hand, a population learns institutional politics at schools: institutional basis of democracy, political parties, levels of administration, citizens' rights, values related to social participation, and religions among others. On the other hand, they learn the history of social movements in Europe, national and regional culture; for example Andalusian culture as a narrative based on symbols, myths, beliefs, values, and some other contents whose goal is to strengthen the feeling of belonging to a common reality: the nation.

Moreover, adolescents learn economics in schools: models of production, the economics of knowledge, the working world, and professional relationships. However, as shown by the results in the category of social obligations, adolescents do not make a connection between the world of politics, the nation, and the socio-economic domain. Therefore, this sector of the population perceives as an adult social obligation the responsibility for local issues. They have learned about the concept of global and national citizenship in different subjects isolated in time and space (timetable and school environment). Thus, they give more value to social and emotional contents (peace, environment and human rights, but in the context of "Working hard" only to benefit from money: housing, spending in goods, etc.), and less value to collective benefits in order to improve the community as a common social reality.

\subsection{Views about the homeland.}

The aim of this national and emotional category is to verify the concept of collective civic awareness. The concept of homeland (nation of origin) is repeated in educational systems. Every school has its own flag that represents the nation. In Andalusia, adolescents know the flag of their region and the flag of their country. Which one is their homeland? To whom do adults have to be loyal? Which history must they know? Due to this dualism, the results 
of this category influencing civic awareness among adolescents must be studied in a generic way: there is no reference of specific homeland. Therefore, the most significant result is the one emotionally related to the loyalty to the country, where this aspect is emphasised. Moreover, the negative connotation of the concept of homeland (the generations raised in the dictatorship learned this concept associated to an authoritarian idea instead of to a political interpretation of it) still influences the fact of not mentioning it, as well as the national flag. This is not common in the European context of other member states. The rational argument of this emotional view of the homeland is based on the data of the INJUVE report (Funes Rivas, 2008). On the one hand, adolescents do not give the right value to the country's institutions (central and autonomic government), and the representative institutions of national and regional politics (parliaments, political parties and politicians) that constitute the elements of reference of the homeland in democratic terms. The reasons of this poor appreciation are clear in other studies (Autumn Barometer of the CIS, Spanish Centre for Sociological Research, 2009), where the politicians (the representatives of the homeland) are seen as a social and political problem for the Spanish population, and adolescents are aware of that. On the other hand, the curricular instruments to foster the knowledge about the homeland (the history of every nation) do not influence adolescents' civic awareness. In Chart I only a third part of the population seems to see the knowledge about the history of the nation as a patriotic obligation.

Only in sport activities (defending the homeland) can this sense of collective belonging be seen through the symbols of the flag, the anthem, loyalty to the "national t-shirt" and union of the nation-state for a common goal, to win the competition (Moscoso, 2006). This emotional defence or "support to the national team" is added to the honour of joining the army as a patriotic obligation. This recruitment process is repeated in every nation: the army means adventures, national pride, personal esteem to contribute to the improvement of the homeland, autonomy and becoming an adult. However, this is a momentary feeling (Spanish Economic and Social Council, 2008; Elzo, Feixa, \& Giménez, 2007), not a conviction for becoming a permanent member of the army.

\section{Debate.}

The international works mentioned here about the concept of civic awareness among adolescents are closer to a cognitive and social view than to an emotional one, which means a weak perception of civic awareness. The Andalusian case is a clear example of this.

The countries that took part in the CiVed'99 study defined their citizenship politics from a perspective based on the knowledge of rights, responsibilities and citizens' obligations. Two sources of information have been selected to illustrate this international situation regarding the definition of identity and civic awareness of adolescent populations: the work of Kennedy (2010) and the work of Judith Torney-Purta, Lehmann, Oswald, and Schulz (2001). The study carried out by Torney-Purta refers to the traditional vision of citizenship defined by the states without taking into account the daily behaviour of citizens (Martín Gordillo, 2006). This paradigmatic "deficiency" leads to upsetting results (passive vision of citizenship), although it is due to the wrong design of the study: it did not take into consideration the topics that foster citizenship and civic awareness 
among the adolescent population because it was centred in the literature of representative liberal democracy.

Another reference work is the one carried out by Kerry Kennedy. This author concludes, as in this work, that the meaningful elements influencing civic awareness in Europe (Kennedy, 2010) are: both men and women identify being a good adult citizen to political, civic and patriotic obligations learned at schools, in their families, or through the media
(Kennedy, 2007; Kennedy, \& Chow, 2008). For this international adolescent population, the most important aspect is to abide the law, work hard, and be loyal to their country.

This author concludes that the veracity of this data is insufficient because, according to him, it is necessary to consider the social and cultural context of every adolescent in order to obtain a more precise idea of citizens' behaviour and the important issues for them.

\begin{tabular}{|l|c|c|c|c|}
\hline & \multicolumn{2}{|c|}{ Men } & \multicolumn{2}{c|}{ Women } \\
\hline & $\mathrm{M}$ & $\mathrm{SD}$ & $\mathrm{M}$ & SD \\
\hline 1. To abide the law & 3.60 & .716 & 3.69 & .596 \\
\hline 2. To vote in national elections & 3.03 & .732 & 3.07 & .672 \\
\hline 3. To participate in a political party & 2.16 & .814 & 2.11 & .720 \\
\hline 4. To work hard & 3.33 & .738 & 3.37 & .685 \\
\hline 5. To participate in a pacific protest against an unfair law & 2.71 & .897 & 2.65 & .845 \\
\hline 6. To know the history & 2.85 & .879 & 2.80 & .848 \\
\hline 7. To be willing to join the army to defend the country & 2.39 & .947 & 2.43 & .848 \\
\hline 8. To follow political topics in newspapers, radio and TV & 2.81 & .783 & 2.86 & .717 \\
\hline 9. To take part in activities benefiting the community & 3.00 & .726 & 3.14 & .647 \\
\hline 10. To show respect for the representatives of the & 2.93 & .796 & 3.02 & .690 \\
\hline 11. To take part in activities promoting human rights & 3.03 & .798 & 3.05 & .747 \\
\hline 12. To be involved in political debates & 2.58 & .825 & 2.55 & .771 \\
\hline 13. To take part in activities for protecting the environment & 3.07 & .835 & 3.19 & .738 \\
\hline 14. To be patriotic and loyal to the country & 3.12 & .811 & 3.11 & .765 \\
\hline 15. A law violating human rights could be ignored & 2.59 & 1.05 & 2.59 & 1.013 \\
\hline
\end{tabular}
$\mathrm{p}<.05 \quad$ Source: Kennedy, K. 2010 (shown in the newspaper)

Therefore, the perceptions of a good citizen are influenced by economic and political circumstances, the culture of every community, the family environment, educational prospects, and the socio-cultural capital of every adolescent. Moreover, for other authors the first element of citizen's reference point and influence is the relationship with their family and their friends (Theiss- Morse, \& Hibbing, 2005; Bronfenbrenner, 1974; 1977, 1987), as well as the education method followed for teaching Civic Education at schools. Depending on these contexts, the citizenship's vision can be corporative, when it only refers to the rights acquired thanks to the political power, or active when the citizenship's reference point is civil society.

This work, based on the different ways of life among an adolescent population, illustrates the existence of different citizenship practices, knowledge and civic skills, depending on the history, traditions, wealth and resources of the countries, their prospects and political ambitions, as well as a diversity of factors defining a society. This accumulation process is denominated by Pierre Bordieu (2006) Social Capital, which, according to the author, in its physical and objective forms takes time to build itself up and which, thanks to its potential ability to produce benefits, persists in the evolution of the accumulation process because it is present in the objectivity of the things, as everything is equally possible and impossible.

This leads to a dilemma: the development of topics fostering citizenship in the local 
context does not take into account national and global issues, and it influences the development of civic awareness. The consequence of this exclusion is that the ability of understanding and proceeding of adolescents in the social, cultural and economic reality (globally and individually) in the XXI century is not strong enough (House, Hanges, Javidan, Dorman, Gupta, 2004).

\section{Conclusion: learning about politics.}

The main conclusion of this work is to develop the political learning process of adolescents using their social and emotional concerns as points of departure (Richardson, 1990; Romano, \& Glascock, 2002; Peter Lang, Rudduck, \& Flutter, 2000; Smith \& Wohlstetter, 2001; Streibel, 1998). The knowledge of traditional citizenship issues (legislation, civil rights, social movements' history, and the history of their nation among others) is less influenced in their civic awareness than daily and personal issues that foster their learning process about democracy and socio-political participation.

This vision is the new educational pattern for citizenship. The key elements for this pattern are the following:

-People as individuals who try to find their own identity (Giddens, 1991).

-Orientation to foster individuals and groups' autonomy process.

-Relation to the distribution of power and resources in the local environment of adolescent population.

-Practice in relation to ethical justice, equality and participation in local environments.

-Basis on the demands, concerns, ideologies and interests of the studied population.

-Globality in the sense of learning in the social and cognitive areas.

-Presence in the areas of human and personal development, and the ability to find learning resources and action proposals.

-Application to the development of new social movements through informal and formal interaction networks in the field of collective action and identity.

The institutional and social development of this pattern is based on four points of reference for the adolescent population: civic knowledge and practice at schools, the ability of action of every individual, school organisation, and social capital. These four social and institutional points of reference constitute independent actions included in the learning concept of active citizenship: ability of every individual and human group of solving practical problems, strengthening the influence of social change in political and social organisations and institutions, and finally civic awareness based on collective action as an understanding process for freedom and autonomy restrictions.

\subsection{Subject.}

Civic knowledge: to provide students with the knowledge about the rules and codes of citizenship identity; for example, communication skills, the ability to understand the effects of their actions, finding facts, and reaching conclusions. Other examples are the critical thinking process and the ability to solve problems, as well as analytical skills for identifying facts. We also find production skills, which means taking a concept and implementing it, the ability of evaluating group actions, and the ability to manage time and determine priorities, engagements, etc. It is important to know how the subject is going to be taught, its contents, etc. Civic Education is meant to train people from a country, especially adolescents, how to act as citizens. It is therefore a political education that fosters 
the virtues of the knowledge and necessary skills for political participation. The teaching method, based on investigations about participative action, is coherent with the basis of active citizenship (Boyle, Fahey, Loughram, \& Mitchell, 2001).

\subsection{Interpretation ability of every individual.}

This learning field constitutes the basis of civic awareness: focusing on topics fostering it. This ability of observation and interpretation of topics important for civic awareness has been defined by citizenship competences and political skills for selecting and synthesising key practical issues. These meta-cognitive strategies allow students to establish and transfer what they have learned to other disciplines and to all the domains of their lives. The interpretative references constitute the elements creating civic awareness among adolescents, so for example: sustainable development regarding energy and water resources, waste management, inclusion and participation, and food and drinks. This interpretative skill influences protests, demonstrations, and the creation of particular topics regarding local and global social movements.

\subsection{Culture and school environment.}

A learning environment based on inclusion and democracy provides the necessary resources for developing citizenship identity. The actions needed in order to foster this democratic environment are: psychosocial relations at schools, cooperation between different participants, relations among students, physic and mental health, leadership, rules and values, physical environment of work and students' participation.

The efficiency of the school as a promoter of civic awareness among adolescents has been a problematic issue due to the antidemocratic context at schools and the excessive importance given to intellectual development. Activities of social development at school and the dialogue with the families create positive effects regarding awareness about democracy. It is the strongest and most significant effect of the participation in activities of social development at schools thanks to activities oriented to leadership.

It is also relevant to investigate about the role of schools regarding the learning process of social skills. The findings show that school capital moderately affects the creation of a civic awareness, while the family capital remains the strongest one. Cultural capital also has an influence on school success. Two hypotheses can be mentioned: one is that the status of the parents is positively linked to the academic performance of the student, and another is that the positive effect of the socioeconomic status of the parents also influences positively the cultural capital or cultural participation.

\subsection{Social and cultural capital.}

The development of volunteering processes and the participation in local associations are elements focused in the associative practice, which is very important for the social and cultural capital. The strength of the social capital thanks to non-profit organisations and civil associations constitutes the framework of social learning based on the experience of direct social structures and resources. Moreover, the connection between schools and families fosters school and families fosters school success, which influences the citizenship's learning process (Adeyemo, 2000).

It is unclear how people's involvement in young centres and the media's action influence civic awareness. It is important to know if the engagement in the social development of activities, volunteering, community service and leadership 
training contributes to fostering civic awareness regarding democracy. It seems that some means of participation and democratic development have contributed to adolescents' civic awareness. Socialisation experiences, democracy applied to the contexts where they live, different ways of participation and democracy are some examples. Other leading elements are those related to the social capital as social progress, which is more of a considerable factor of the creation of civic awareness than some other forms of social engagement; communication and debates in the familiar environment greatly influence the fostering of civic awareness.

The habitus is the mechanism allowing people to estimate their social and cultural capital, which influences their success in different fields, their participation, etc., because social capital refers to social networks and social interactions, which facilitate good school results. These school results are studied from three different positions: structural, which means establishing connections between key players who share information, and also social structures examined from outside, such as networks, associations and institutions. The third one is relational and cognitive, which means being part of a group and being able to develop together a set of goals and to share an organised vision.

In the following works, the influence of the mentioned references in the creation of civic awareness among adolescent population will be studied. Thanks to it, we will obtain a closer knowledge about citizenship behaviour of adolescents. The outcomes of this study will allow us to take more precise decisions regarding scholar and social politics (Calvo de Mora, 2010), which means the creation of new school domains based on participation, exchange of ideas, development of virtues such as honesty, being open, flexible and compassionate, and also to encourage personal identity and esteem of every member of the school community.

\section{References}

Adeyemo, D.A. (2000). Parental involvement, interest in schooling and school environment as a predictor of academic self-eficacy among fresh secondary school student in Oyo State, Nigeria. Electronic Journal of research in Educational Psychology, 3(5), 163-180. [Full text] [Back to text]

Aguiar, F. (1995). Informe sobre el tercer sector en Andalucía. IESAA/CSIC: Sevilla. [Back to text]

Alonso, L.E. (1999). La juventud en el tercer sector: redefinición del bienestar, redefinición de la ciudadanía. Revista de Estudios de la Juventud, 45, 9-20. [Full text] [Back to text]

Arendt, H. (2008). La promesa de la política. Barcelona: Paidós. [Abstract] [Back to text]

Audigier, F. (2000). Basic concepts and core competences of education for democratic citizenship.

Estrasburgo: Publicaciones del Consejo de Europa. [Full text] [Back to text]

Barber, B. (1984). Strong democracy: participatory politics for a new age. Berkeley: Editora de la Universidad de California. [Abstract] [Back to text]

Barnes, R. (2004) Citizenship in practice. British Journal of Social Psychology, 43(2), 187-206. [Abstract] [Back to text] 
Beck, U. \& Beck-Gernsheim, E. (2002). Individualization. Institutionalized individualism and its social and political consequences, Londres: Sage Publication. [Abstract] [Back to text]

Benedicto, J. \& Morán, M.L. (2002). La construcción de una ciudadanía activa entre los jóvenes. Madrid: INJUVE. [Full text] [Back to text]

Bens, C. (2001). What does it mean to be a good citizen? National Civic Review, 90(2), 193-198. [Abstract] [Back to text]

Birks, P. (Ed.). (1997). The classification of obligations. Nueva York: Oxford University Press. [Abstract] [Back to text]

Blondiaux, L. \& Sintomer, Y. (2004). El imperativo deliberativo. Estudios Políticos, 24, 95-114. [Full text] [Back to text]

BOE (2006). Real Decreto 1513, de 7 diciembre de 2006, por el que se regula la educación para la ciudadanía en la Educación Primaria. Boletín Oficial del Estado, N 293. [Full text] [Back to text]

BOE (2007). Real Decreto 1631 de 29 de Diciembre de 2006 por el que se regula la educación para la ciudadanía en la Educación Secundaria. Boletín Oficial del Estado, N 5. [Full text] [Back to text]

Bordieu, P. (2006). The forms of Capital. In A.R. Sadovnik, (Ed.), Sociology of education. Acritical reader (pp. 83-93). [Abstract] [Back to text]

Borja, J. (2000). Ciudad y ciudadanía. Dos notas. Barcelona: Institud de
Ciències Polítiques i socials. [Full text] [Back to text]

Bronfenbrenner, U. (1974). Development research, public policy, and ecology of childhood. Child Development, 45, 105-115. [Full text] [Back to text]

Bronfenbrenner, U. (1977). Toward an experimental ecology of human development. American Psychologist, 32(7), 513-531. [Abstract] [Back to text]

Bronfenbrenner, U. (1987). La ecología del desarrollo humano. Barcelona: Paidós. [Full text] [Back to text]

Caínzos, M. (2006). La participación de los jóvenes españoles en manifestaciones. Comparación con los jóvenes europeos y análisis de sus determinantes. Revista de Estudios de Juventud: Movilización social y creatividad política de la juventud, 75, 121-154. [Full text] [Back to text]

Calvo de Mora, J, \& Morales, J.A. (2008). Towards a new paradigm of school organization: insterationism inclusiveness. In J.Calvo de Mora (Ed.), Sharing responsibilities and networking through school process (pp. 7-44) [Back to text] [Abstract]

Calvo de Mora, J. (1999). Claves para la organización de la práctica escolar. Granada: Método. [Back to text] [Abstract]

Calvo de Mora, J. (2006). Aprendizaje de la ciudadanía en las escuelas. Granada: Consejo Escolar de Andalucía. [Back to text] [Abstract]

Calvo de Mora, J. (2007). An Open Model of Schooling: Developing 
Education for Sustainability Projects. En A. Pipere (Ed.), Education and Sustainable Development: First Steps toward Changes. [Back to text] [Abstract]

Calvo de Mora, J. (2010) Liderazgo social en las escuelas. In press. [Back to text]

Cazorla, J. (1992). Del clientelismo tradicional al clientelismo de partido: evolución y características, ICPS, 55. [Back to text] [Full text]

Ceslik, M \& Pllock, G. (Eds.). (2002). Young people in risk society. The restructuring $f$ youth identities and transitions in late modernity. Aldershot: Ashgate. [Back to text] [Abstract]

Chaux, E. (2005). Estándares básicos de competencias ciudadanas: estructura y proceso de construcción", documento presentado en el Taller Internacional de Formación en Competencias Ciudadanas, Ministerio de Educación Nacional; OEA. Oficina de Educación, Ciencia y Tecnología, Bogotá, 25 al 28 de abril. [Full text] [Back to text]

Chaves Ávila, R. \& Monzón Campos, J.L. (2005). La economía social en la Unión Europea. CIRIEC. [Full text] [Back to text]

Cheung, C-K.; Lee, T-Y.; Chan, W.-T.; Liu, S.-Ch.; Leung, K-K. (2004). Developing civic consciousness through social engagement among Hong Kong youth. The social science. 41, 651-660. [Abstract] [Back to text]

CIS (2009). Barómetro de Otoño, 2009. Madrid: Publicaciones del Consejo de Investigaciones Sociológicas. [Back to text]

Coleman, J.S. (1997). Social Capital and the Creation of Human Capital. In A.H. Halsey, H. Lauder, P. Brown y A.S. Wells (Eds.), Education: culture, economy, society (pp 8095). [Full text] [Back to text]

Coleman, P. (1998). Parent, Student and Teacher Collaboration: the Power of Three. Londres: Paul Chapman. [Abstract] [Back to text]

Consejo de Europa (2001). Education for democratic citizenship activities 2001-2004. Estrasburgo: Ediciones del Consejo de Europa. [Full text] [Back to text]

Consejo de Europa (2003). Transitions of youth citizenship in Europe. Culture, subculture and citizenship. Estrasburgo: Ediciones del Consejo de Europa. [Full text] [Back to text]

Consejo Económico y Social de España (2008). La transición educativaformativa e inserción laboral de los y las jóvenes en España, Revista Cauces, 33, 28-47. [Full text] [Back to text]

Cortina, A. (2004, 24 de agosto). Democracia deliberativa. Diario El País. [Full text] [Back to text]

Dagger, R. (2007). Political obligations. In E. Zalta (Ed.), The stanford Enciclopedia of Philosophy. [Full text] [Back to text]

Dalton, R. (1996). Citizen Politics. Chatham: Chatham House Publication. [Abstract] [Back to text]

Dede, C. (1992). Education in the 21st century. Annals of the American 
Academy for Political and Social Science. 522, 104-115. [Abstract] [Back to text]

Delors, J. (1996). La educación encierra un Tesoro. Informe a la UNESCO de la Comisión Internacional sobre Educación para el siglo XXI. Madrid: Santillana, UNESCO. [Full text] [Back to text]

Delue, S. (1989) Political Obligations in a liberal state. Albany: Editorial de Universidad del Estado de Nueva Cork. [Back to text]

Dewey, J. 1976/[1938]. Experience and Education. New York: Collier/Macmillan. [Full text] [Back to text]

Dewey, J. 1991/[1910]. How We Think. New York: Prometheus Books. [Abstract] [Back to text]

Dewey, J. 2004 [1916]. Democracy and Education, Mineola, Nueva York: Dover Publications. [Back to text]

Domínguez, M. \& Sádaba, I. (2005). Transformaciones en las prácticas culturales de los jóvenes. De la lectura como ocio y consumo a la fragmentación neotecnológica. Revista de Estudios de Juventud: Jóvenes y lectura, 16, 23-38. [Abstract] [Back to text]

Eder, K. (2000). Social Movement Organizations and the Democratic Order: Reorganizing the Social Basis of Political Citizenship in Complex Societies. In C. Crouch, K. Eder \& D. Tambiani (Eds.), Citizenship, markets and the state. (pp 213-237). [Full text] [Back to text]

Elzo, J., Feixa, C. \& Giménez, E. (2007). Jóvenes y valores, la clave para la sociedad del futuro. Barcelona: La Caixa. [Full text] [Back to text]

Eurydice (2005). Citizenship education at school in Europe. Comision Europea: Bruselas. [Full text] [Back to text]

Freire, P. (1972). Pedagogía del oprimido. Buenos Aires: Siglo XXI. [Abstract] [Back to text]

Freire, P. (1973). Education for critical conciousness. Nueva York: Continuum. [Full text] [Back to text]

Freire, P. 2006/[1970]. Pedagogy of the Oppressed. New York: Continuum. [Abstract] [Back to text]

Funes, M.J. (2008). Informe 2008: Juventud en España: Cultura, política y sociedad. Madrid: Instituto de la Juventud. Ministerio de Igualdad. Tomo $4 . \quad$ [Full text] [Back to text]

García Benitez, A. (2000). Estructura social de Andalucía; análisis de un modelo pedagógico de la disciplina. Sevilla: Padilla Libros. [Abstract] [Back to text]

Giddens, A. (1991). Modernity and SelfIdentity: Self and society in the late-modern age. Cambridge: Polity press. [Full text] [Back to text]

Giddens, A. (Ed.). (2003). The Progressive Manifesto: New Ideas for the Centre Left. Cambridge: Polity. [Abstract] [Back to text]

Gilbert, M. (2006). A theory of political obligation: Membership, commitment, and the bonds of society. Nueva York: Oxford University Press. [Abstract] [Back to text] 
Gómez Llorente, L. (2005). La educación para la ciudadanía. Escuela. N 3665. [Abstract] [Back to text]

Hahn, C. (1998). Gender and political learning. Theory and Research in social education. 24(1), 8-35. [Abstract] [Back to text]

Hollander, E.L.; Saltmarch, P. \& Zlotkowski, E. (2001). Indicators of engagement. In L.A. Simon, \& asociados (Eds.), Learning to serve: promoting civil society through service learning, (pp.) [Abstract] [Back to text]

House, R.J., Hanges, P. J., Javidan, M., Dorman, P.W. \& Gupta, V. (2004). Culture, Leadership, and Organizations. The globe study of 62 societies. Londres: Sage publications. [Abstract] [Back to text]

Husfeldt, V., Barber, C. y Turney-Purta, J. (2005). Studens' social attitudes and expected political participation: new Scales in the enhanced database of the IEA Civic Education Study. Working Paper from CEDARS.

http://www.umd.edu/-jtpurta/. [Back to text]

Iacovou, M. \& Berthoud, R. (2004). Social Europe: living standards and welfare states. Edward Elgar Publishing. [Back to text] [Abstract]

Ichilov, O. (Ed.). (1990). Political socialization, citizenship, education and democracy. Nueva York: teachers College. [Abstract] [Back to text]

Iyamu, E.O.S. \& Obiunu, J.J. (2005). Impact of citizenship education on the civic conciousnessof Nigerian youth. Journal of Instructional Psychology, 3, 305-327. [Full text]
[Back to text]

Janowitz, M. (1983). The reconstruction of Patriotism. Education for civic consciousness. Chicago: Editorial de la Universidad de Chicago. [Abstract] [Back to text]

Kennedy, K., Hahn, C., \& Lee, W. O. (2006). Becoming Apolitical: A comparison of students' construction of citizenship in the United States Australia and Hong Kong. Paper presented at the Annual Conference of the Comparative and International Education Society, Honolulu. [Abstract] [Back to text]

Kennedy, J.K., Lee, W.O. \& Grossman, D. L. (2010). Citizenship pedagogies in Asia and the Pacific. Hong Kong: Springer. [Abstract] [Back to text]

Kennedy, K. \& Chow, J.F.K. (2008). A Comparison of Hong Kong and European Union Students Conceptions of the 'Good Citizen'. Hong Kong: Hong Kong Institute of Education. [Back to text]

Kennedy, K. (2007). Student construction of "active citizenship": What does participation mean to students? British Journal of Educational Studies, 55, 304-324. [Back to text] [Abstract]

Kennedy, K. J. (2010). Young Citizens in Hong Kong: Obedient, Active and Patriotic? Social Psychology of Education, 13(1), 111-127. [Abstract] [Back to text]

Klosko, G. (2005). Political Obligations. Oxford: Editorial de la Universidad de Oxford. [Abstract] [Back to text]

Kurtz, K.T., Rosenthal, A., \& Zukin, C. (2003). Citizenship. A challenge 
for All generations. National conference of state legislatures. Center for Civic Education. Denver, Colorado, EE.UU. [Full text] [Back to text]

Lantieri (2009). Inteligencia emocional infantil y juvenil Madrid: Aguilar. [Abstract] [Back to text]

Luhmann, N. (1979). Trust and power: two works John Wiley \& Sons: Chichester. [Back to text]

Luhmann, N. (1988). Familiarity, confidence, trust: problems and alternatives (in) D. Gambetta (Ed.), Trust: Making and Breaking of Cooperative Relations (pp. 94107). [Full text] [Back to text]

Lyakhosvetska, R., Burman, K., Takeda, M., Maxwell, J., Pillas, S. \& Wong, D. (2003). Looking into the future. Views of UBC Students and alumni on Global Citizenship. Global Citizenship Project. Universidad de la Columbia Británica. [Full text] [Back to text]

March, J. \& Olsen, J. (1996). El Nuevo institucionalismo: factores organizativos de la vida política. Zona Abierta, 63-64. [Full text] [Back to text]

Marshall, T. H. (1977). Class, Citizenship and Social Development, Chicago and London: Chicago University Press. [Full text] [Back to text]

Marshall, T. H. (1981). The Right to Welfare and Other Essays. Londres: Heinemann Educational. [Full text] [Back to text]

Martín Cortés, I. (2006). Una propuesta para la enseñanza de la ciudadanía democrática en España. Madrid: Fundación alternativas. [Full text] [Back to text]

Martin Gordillo, M. (2006). Conocer, manejar, valorar, participar: los fines de una educación para la ciudadanía. Revista Iberoamericana de Educación. 42, 69-83. [Full text] [Back to text]

McNeal, R.B. (1999). Participation in high school extracurricular activities: Investing school effects. Social Sciences Quarterly, 80, 291-309. [Back to text]

Megías Valenzuela, E. (Coord.) (2005). Jóvenes y política. El compromiso con lo colectivo. Madrid: INJUVE, Fad. Obra Social Caja de Madrid. [Full text] [Back to text]

Misztal, B. (1996). Trust in modern societies: the search for the bases of social order. Cambridge: Polity Press. [Abstract] [Back to text]

Moscoso, D. (2006). La sociología del deporte en España. Estado de la cuestión, Revista Internacional de Sociología, 45, 177-204. [Abstract] [Back to text]

Müller, J-W (2006). On the origins of constituional patriotism. Contemporary Political Theory, 5, 278-290. [Abstract] [Back to text]

Naval, C. (2008). Universidad y conciencia Cívica. Revista Sembrando Ideas, 2, 1-23. [Full text] [Back to text]

Nie, N.H., Junn, J. \& Stehlik-Barry, K. (1996). Education and democratic citizenship in America. Chicago: University of Chicago Press. [Abstract] [Back to text]

O'Brien, J. (2008). Are we preparing young people for 21 st -century 
citizenship with $20^{\text {th }}$-century. thinking? A case for a virtual laboratory of democracy. Contemporary Issues in Technology and Teacher Education [Online serial], 8(2), 125-157. [Full text] [Back to text]

Owen, D. \& Dennis, J. (1992). Sex differences in politicization: The influence of mass media. Women and Politics, 12(4), 19-41. [Abstract] [Back to text]

Parekh, B. (1993). A misconceived discourse on political obligations. Political Studies, 41, 236-251. [Abstract] [Back to text]

Parés, M. (Cord.) (2009). Participación y calidad democrática. Madrid: Ariel. [Abstract] [Back to text]

Reason, P. \& Bradbury, H. (Eds.). (2002). Handbook of Action Research. Perspective inquiry \& practice. Londres: SAGE, publications. [Abstract] [Back to text]

Reimers, F. (2006). Citizenship, identity and Education: examining the public purposes of schooling in an age of globalization. Propects, XXXVI (3), 275-294. [Abstract] [Back to text]

Richardson, L. (1990). Writing strategies: Reaching diverse audiences. London: Sage. [Abstract] [Back to text]

Rodríguez, E., Megías, I. \& Sánchez, E. (2002). Jóvenes y relaciones grupales. Dinámica relacional para los tiempos de trabajo y ocio. Madrid: INJUVE. [Full text] [Back to text]

Romano, R.M. \& Glascock, C.H. (2002). Hungry minds in hard times. Educating for complexity for students of poverty. New York: Peter Lang. [Abstract] [Back to text]

Schulz, W. \& Sibberns, H. (2004). Technical report on the IEA Civic Education Study. Amsterdam: International Association for Educational Assessment. [Full text] [Back to text]

Segovia, J.F. (2008). Habermas y la democracia deliberattiva. Madrid: Marcial Pons. [Abstract] [Back to text]

Shapiro, R. \& Majan, H. (1986). Gender differences in policy preferentes: A summary of trends from 1960s to the 1980s. Public Opinion Quarterly, 50, 42-61. [Full text] [Back to text]

Smith, AK \& Wohlstetter, P. (2001). Reform through school networks: A new kind of authority and accountability. Educational Policy, 15(4), 499-519. [Full text] [Back to text]

Streibel, M.J. (1998). Information technology and physicality in community, place and presence. Theory Into Practice, 37(1), 31-37. [Full text] [Back to text]

Taglioli, A. (2007). Globalización e individualización: la construcción modular de la identidad juvenil. Sistema, $\quad$ 197-198, 73-84. [Abstract] [Back to text]

Tezanos, J. F. (2007). Juventud, ciudadanía y exclusión social. Sistema, 197-198, 103-120. [Abstract] [Back to text]

Theiss- Morse, E. \& Hibbing J. R. (2005). Citizenship and Civic Engagement. Annual Review of Political Science, 8, 227-249. [Full text] [Back to text] 
Torney-Purta, J., Lehmann, R., Oswald, H., \& Schulz, W. (2001). Citizenship and education in twenty-eight countries: Civic knowledge and engagement at age fourteen. Amsterdam: IEA. [Full text] [Back to text]
Unión Europea (2005). La educación para la ciudadanía en el contexto escolar europeo. Eurydice, Bruselas. [Full text] [Back to text]

Vygotski, L.S. (1997). Obras escogidas. Madrid: Visor. [Abstract] [Back to text] 